\author{
Arkadiusz Kaźmierczak \\ Uniwersytet Łódzki \\ Wydział Nauk o Wychowaniu \\ Pracownia Wychowania Fizycznego i Zdrowotnego \\ 90-236 Łódź, ul. Pomorska 149/153
}

\title{
Sport, olimpizm i zasada „fair play” jako wartości w życiu osób niepełnosprawnych
}

\section{Streszczenie}

Uniwersalny charakter sportu, jego korzyści dla rozwoju fizycznego, emocjonalnego i społecznego wraz z wychowawczymi walorami uczestnictwa w określonych formach aktywności fizycznej są skutecznym środkiem do eliminacji stygmatu związanego z niepełnosprawnością. Sport jako fenomen współczesnej kultury i wychowania, poprzez sytuacje, które nawiązują do szeroko pojętego humanizmu w znacznym stopniu przyczynia się do wspierania socjalizacji, niezależności, inicjacji i pełnej integracji. Aktywność fizyczna, idea olimpizmu i postępowanie zgodnie z ustalonymi regułami „fair play” są także alternatywną drogą do uzyskania przez osoby niepełnosprawne wiary we własne możliwości, eliminacji skutków inwalidztwa czy też obszarem dla podniesienia jakości życia oraz wzmocnienia więzi rodzinnych i społecznych. W tym kontekście sport nie powinien mieć charakteru elitarnego, lecz powinien charakteryzować się masowym uczestnictwem osób niepełnosprawnych w rekreacyjnej i kwalifikowanej aktywności sportowej.

Słowa kluczowe: sport, olimpizm i zasada „fair play” osób niepełnosprawnych.

Współczesny rozwój cywilizacji, który dokonuje się w warunkach koniunkturalnej i dynamicznej rzeczywistości, stwarza z jednej strony znaczne możliwości dla rozwoju człowieka, z drugiej jednak stanowi poważne zagrożenia i wyzwania dla naszego zdrowia, a tym samym przyczynia się do wzrostu liczby osób niepełnosprawnych. Bank Światowy szacuje, że około 650 milionów ludzi, czyli 10\% ludności świata, cierpi na różnego rodzaju defekty rozwojowe, wykazuje niezdolność do wykonywania pracy zawodowej lub posiada znaczny stopień niepełnosprawności. W procesie rehabilitacji istotna jest postawa osoby niepełnosprawnej wobec uszkodzeń wraz z możliwościami 
pokonywania ograniczeń wynikających z własnych ułomności. Na tym gruncie dosyć powszechnym zjawiskiem jest negatywna ocena własnych możliwości, stres spowodowany bezsilnością, niechęć do podejmowania jakiejkolwiek aktywności oraz poczucie niższej wartości społecznej. W tej sytuacji na pierwszy plan wysuwa się cel wychowawczy, który powinien odnosić się do przekonania, że „nie ma kaleki, jest człowiek”, który stanowi nadrzędną wartość również wtedy, kiedy jest w określonym wymiarze osobą niepełnosprawną. Wartość życia - zdaniem Grzegorzewskiej (1996, list dziesiąty) - „,...] zależy, zawsze przede wszystkim od jakości jej treści, uzależnionej od wartości człowieka, który ją tworzy, rozwija i buduje. Musi więc ją tworzyć człowiek wolny, etyczny, uspołeczniony i pełny [...]”. Z kolei Biniakiewicz (1994, s. 356) wskazuje na konieczność dopracowania u osoby niepełnosprawnej wizji ukazującej sens i wartości życia „,[...] jest to doświadczenie egzystencjalne, ale bez poczucia sensu życia nie możemy oczekiwać u wychowanka aspiracji do podmiotowości”. Wskazana koncepcja jest wyrazem globalnie pojętego humanitaryzmu, zgodnie z którym społeczeństwo powinno każdą, choćby najbardziej niepełnosprawną, jednostkę traktować na równi z innymi we wszystkich przejawach życia społecznego.

Poglądy na funkcjonowanie osób niepełnosprawnych w społeczeństwie uległy na przestrzeni ostatnich dekad istotnym zmianom, kształtując się pod wpływem ,innego spojrzenia” na osobę niepełnosprawną, utrwalając przekonanie o ich prawach do normalnego i godnego życia. Wydaje się, że jednym ze skutecznych kierunków kreowania wartości pozytywnych u osób niepełnosprawnych jest ich aktywne uczestnictwo w kulturze fizycznej, ze szczególnym wskazaniem rekreacyjnej i kwalifikowanej aktywności sportowej. Maszczak (1997, s. 226) twierdzi, że „[...] utrwalenie godnej postawy wobec kalectwa i własnego zdrowia wiąże się nierozerwalnie z pełnym i twórczym uczestnictwem w różnych formach aktywności ruchowej, do których możemy zaliczyć wychowanie fizyczne i sport osób niepełnosprawnych, dając im tym samym możliwość przejścia od izolacji do pełnej integracji ze środowiskiem ludzi pełnosprawnych”. Wszystkie dostępne formy zajęć sportowych i rekreacyjnych, w których osoba niepełnosprawna bierze udział, stwarzają korzystną sytuację dla poprawy stanu zdrowia i eliminacji skutków niepełnosprawności, dając również możliwości pełnego uczestnictwa we wszystkich przejawach życia społecznego.

Sport i olimpizm osób niepełnosprawnych nie jest nową inicjatywą, chociaż posiada krótką historię w porównaniu z ponad stuletnim istnieniem nowożytnego ruchu olimpijskiego reaktywowanego przez francuskiego barona Pierre de Coubertina. Podczas II wojny światowej do rozwoju sportu osób niepełnosprawnych w znacznym stopniu przyczynili się lekarze A. von Mallwitz z Niemiec oraz R. Watson-Jones z Anglii, którzy zalecali żołnierzom rannym na skutek 
działań wojennych aktywność fizyczną jako formę rehabilitacji. W 1944 r. neurochirurg dr Ludwig Guttmann w podlondyńskim szpitalu Stoke Mandeville wprowadził zajęcia sportowe do programu usprawniania paraplegików. Realizując swoje zamierzenia, był przekonany, że sport w rehabilitacji niepełnosprawnych jest efektywnym środkiem powrotu do świata zewnętrznego poprzez integrację tych osób ze środowiskiem społecznym. Wzorując się na idei nowożytnego olimpizmu, miał świadomość, że idea olimpizmu nawiązuje do nurtu światopoglądu humanistycznego, tworząc fundament dla kultury fizycznej i sportu, nadając im wysokie miejsce w hierarchii społecznej. Był przekonany o znaczącej społecznej, zdrowotnej i wychowawczej roli sportu w kształtowaniu osobowości każdego człowieka niepełnosprawnego. Początek zorganizowanego na poziomie światowym sportu osób niepełnosprawnych datuje się na dzień 28 lipca 1948 r., kiedy w dniu otwarcia Igrzysk Olimpijskich w Londynie L. Guttmann zorganizował zawody łucznicze dla 16 weteranów wojennych na wózkach inwalidzkich. Dwanaście lat później w Rzymie odbyły się pierwsze letnie igrzyska paraolimpijskie, które były w pewnym wymiarze oderwane od tradycji i idei współczesnego olimpizmu. Dopiero w 1988 r. w Seulu po raz pierwszy sportowcy niepełnosprawni mogli rywalizować o medale paraolimpijskie na tych samych obiektach sportowych, na których odbywały się letnie Igrzyska XXV Olimpiady. Polscy sportowcy niepełnosprawni zadebiutowali w roku 1972 na Igrzyskach Olimpijskich w Monachium (zawody odbywały się w Heidelbergu), zdobywając 33 medale (14 złotych, 12 srebrnych, 7 brązowych). Jednak największy sukces polscy sportowcy niepełnosprawni odnieśli w 1980 r. w Arnhem. Reprezentacja licząca 80 zawodników zdobyła aż 177 medali, w tym 75 złotych, zajmując pierwsze miejsce w klasyfikacji medalowej przed takimi państwami jak USA, RFN i Kanada.

Aktualnie sport osób niepełnosprawnych rozrósł się do kilkunastu ważnych zawodów sportowych o randze międzynarodowej, w tym trzech na poziomie olimpijskiej rywalizacji sportowców niepełnosprawnych - Deafympics (dla osób z wadami słuchu), igrzysk paraolimpijskich (dla osób z niepełnosprawnościami fizycznymi i intelektualnymi, w tym także niepełnosprawnych z problemami mobilności, po amputacjach kończyn oraz utratą wzroku i porażeniem mózgowym) oraz Special Olympics (dla osób z niepełnosprawnością intelektualną). Sport uprawiany przez osoby niepełnosprawne w znacznym stopniu wzorowany jest na organizacji sportu ludzi pełnosprawnych (przepisy, konkurencje), a tym samym jest dostosowany do możliwości funkcjonalnych oraz rodzaju i stopnia niepełnosprawności danej jednostki. Klasyfikacja osób niepełnosprawnych do określonej dyscypliny sportowej polega na podziale zawodników na grupy i zespoły o identycznym lub zbliżonym stopniu inwalidztwa, co stwarza uczestnikom w miarę równe szanse we współzawodnictwie sportowym. 
Tabela 1. Udział i osiągnięcia medalowe polskich sportowców niepełnosprawnych w letnich igrzyskach paraolimpijskich (oprac. M. Iwaniszewska)

\begin{tabular}{|c|c|c|c|c|c|c|c|}
\hline \multirow{2}{*}{$\begin{array}{l}\text { Miejsce igrzysk } \\
\text { paraolimpijskich }\end{array}$} & \multirow{2}{*}{$\begin{array}{l}\text { Liczba } \\
\text { krajów }\end{array}$} & \multicolumn{2}{|c|}{$\begin{array}{c}\text { Liczba } \\
\text { zawodników }\end{array}$} & \multirow{2}{*}{$\begin{array}{c}\text { Złote } \\
\text { medale }\end{array}$} & \multirow{2}{*}{$\begin{array}{l}\text { Srebrne } \\
\text { medale }\end{array}$} & \multirow{2}{*}{$\begin{array}{c}\text { Brązowe } \\
\text { medale }\end{array}$} & \multirow[t]{2}{*}{ Razem } \\
\hline & & razem & Polacy & & & & \\
\hline 1960 Rzym & 17 & 137 & - & - & - & - & - \\
\hline 1964 Tokio & 19 & 239 & - & - & - & - & - \\
\hline 1968 Tel Awiw & 28 & 782 & - & - & - & - & - \\
\hline 1972 Heidelberg & 41 & 926 & 22 & 14 & 12 & 7 & 33 \\
\hline 1976 Toronto & 40 & 1287 & 37 & 25 & 16 & 12 & 53 \\
\hline 1980 Arnhem & 42 & 1652 & 80 & 75 & 50 & 52 & 177 \\
\hline $\begin{array}{l}1984 \text { Nowy Jork i Stoke } \\
\text { Mandeville }\end{array}$ & 54 & 2088 & 34 & 46 & 39 & 21 & 106 \\
\hline $1988 \mathrm{Seul}$ & 60 & 3057 & 47 & 25 & 25 & 33 & 83 \\
\hline 1992 Barcelona & 83 & 3001 & 40 & 10 & 12 & 10 & 32 \\
\hline 1996 Atlanta & 104 & 3259 & 61 & 13 & 14 & 8 & 35 \\
\hline 2000 Sydney & 122 & 3881 & 114 & 19 & 22 & 12 & 53 \\
\hline 2004 Ateny & 135 & 3808 & 104 & 10 & 25 & 19 & 54 \\
\hline 2008 Pekin & 146 & 4011 & 94 & 5 & 12 & 13 & 30 \\
\hline 2012 Londyn & 164 & 4237 & 100 & 14 & 13 & 9 & 36 \\
\hline Razem & & & & 256 & 240 & 196 & 692 \\
\hline
\end{tabular}

Największym i najważniejszym sportowym spotkaniem ludzi niepełnosprawnych są igrzyska paraolimpijskie. Podstawową ideą ruchu paraolimpijskiego jest stworzenie możliwości współzawodnictwa osobom niepełnosprawnym na takich samych kanonach, jak w rywalizacji sportowej zawodników pełnosprawnych. Sportowcy niepełnosprawni uczestniczący w igrzyskach paraolimpijskich ustanawiają rekordy świata i dążą do doskonałości sportowej na miarę własnych - ograniczonych przez inwalidztwo - możliwości fizycznych i psychicznych. Warto podkreślić, że znaczne zaangażowanie i sportowe aspiracje niepełnosprawnych dorównują poziomowi prezentowanemu przez sportowców pełnosprawnych.

Sport zapewnia osobom niepełnosprawnym rozwijanie umiejętności społecznych, nawiązywanie nowych znajomości poza bliskimi osobami, umożliwia 
wykonywanie odpowiedzialnych zadań oraz daje szansę pełnienia w niektórych sytuacjach roli lidera. Przez sport osoby niepełnosprawne nabywają umiejętności rozwijania niezależności, odporności fizycznej i psychicznej oraz zdolności dostosowania się do nowych sytuacji. W ujęciu Wybraniec-Lewickiej (2004, s. 6-8) „[...] sport stanowi alternatywę dla samotności, bezczynności i bezradności osób niepełnosprawnych, dając im szansę na rehabilitację kompleksową. Uprawiany zgodnie z zasadami sztuki trenerskiej, pod pełną kontrolą lekarza sportowego i fizjoterapeuty może być częścią nie tylko szeroko rozumianej rehabilitacji, ale także receptą na lepsze, wartościowsze życie". Milanowska wyróżniła szereg pozytywnych cech współczesnego sportu osób niepełnosprawnych, do których należy zaliczyć:

- oddziaływanie lecznicze, odnosi się do zjawiska sportu jako kontynuacji procesu rehabilitacji, odpowiedniego doboru dyscypliny sportowej pod kątem możliwości funkcjonalnych organizmu i eliminacji określonej dysfunkcji;

- oddziaływanie stymulacyjne, nawiązuje do wszelkiej aktywności ruchowej jako środka terapeutycznego wpływającej na wszystkie układy organizmu człowieka;

- oddziaływanie wychowawczo-psychologiczne, dotyczy kształtowania osobowości osoby niepełnosprawnej w kontekście „wychowania przez sport”;

- oddziaływanie psychologiczne, odwołuje się do tezy, że aktywność sportowa jest także doskonałym środkiem na stres, zmęczenie oraz pokonywanie barier psychicznych;

- oddziaływanie estetyczne, wskazuje, że sport przez typowe środki oddziaływania wyrabia poczucie piękna, pozwala zdobyć nawyki ruchowe, które nie wyróżniałyby osoby niepełnosprawnej od osoby zdrowej;

- oddziaływanie ekonomiczne, odnosi się do wzrostu nakładów finansowych na kulturę fizyczną osób niepełnosprawnych jako świadectwa istotnej wartości społecznej (Milanowska, 1999, s. 23).

Z kolei Z. Żukowska wskazuje na wiele istotnych wartości pedagogicznych w procesie uczestnictwa osób niepełnosprawnych w określonych formach aktywności sportowej. Zalicza do nich między innymi:

- wartości perfekcjonistyczne, które przejawiają się w dążeniu osoby niepełnosprawnej do uzyskania wysokiej sprawności fizycznej w procesie usprawniania lub treningu sportowego;

- wartości emocjonalne mają istotne znaczenie w kontakcie z trenerem, który powinien pełnić funkcję kreatora właściwej postawy sportowej;

- wartości intelektualne, które nawiązują do wiedzy osoby niepełnosprawnej o własnym zdrowiu i możliwości powrotu do normalnego życia;

- wartości socjocentryczne odnoszą się do uzasadnionego przebiegu socjalizacji, czyli nabywania przez osobę niepełnosprawną systemu norm, wartości oraz wzorów zachowań obowiązujących w rodzinie, grupie zawodowej lub sportowej; 
- wartości estetyczne, które z jednej strony dotyczą estetyki ruchu związanej z własną aktywnością sportową, z drugiej - odbioru piękna widowiska sportowego w roli kibica;

- wartości allocentryczne, za sprawą których, osoba niepełnosprawna poprzez samorealizację $\mathrm{w}$ aktywności fizycznej może wnieść w życie społeczne istotne wartości wynikające z jej zdolności i umiejętności przystosowania się do nowej sytuacji;

- wartości zdrowotne znajdują się u podstaw uczestnictwa w treningu sportowym, z tytułu którego wynikają korzyści dla zdrowia fizycznego, psychicznego i społecznego (Żukowska, 1999, s. 29).

Kompetentnej analizy dotyczącej wpływu aktywności sportowej na wybrane sfery życia osób niepełnosprawnych dokonała Sobiecka (2001, s. 41-50), która badaniami objęła grupę 135 sportowców inwalidów (111 mężczyzn i 44 kobiet) - uczestników letnich i zimowych Igrzysk Paraolimpijskich w latach 1972, 1976, 1980, 1984, 1988. Zdaniem niemal wszystkich sportowców badanej grupy (92\%) aktywność sportowa zmniejszyła ich niepełnosprawność w znacznym stopniu, natomiast tylko $8 \%$ sportowców niepełnosprawnych nie dostrzegła istotnych zmian w swoim inwalidztwie. Analizując wpływ treningu sportowego na samopoczucie fizyczne i psychiczne, 94\% sportowców niepełnosprawnych wskazało, że sport ma pozytywny wpływ na kształtowanie osobowości, przyczynia się do lepszej integracji ze środowiskiem społecznym, koncentracji oraz wydolności roboczej. Zapewne z tego względu $62 \%$ paraolimpijczyków nie identyfikowało swojej osoby z inwalidztwem, a $80 \%$ dokonało wysokiej samooceny swojej samodzielności w kontekście ich pełnosprawności, niezależności materialnej, wypełniania obowiązków rodzinnych i zawodowych. Sobiecka w konkluzji analizy uzyskanych wyników badań sformułowała między innymi następujące wnioski:

„1. Sport niepełnosprawnych pełni zarówno funkcje lecznicze, jak i profilaktyczne;

2. Usprawnianie osób niepełnosprawnych poprzez sport wpływa pozytywnie na ich samopoczucie fizyczne i psychiczne;

3. Uprawianie sportu przez niewidomych i niedowidzących prowadzi do kompensacji zaburzonych funkcji narządu wzroku i innych zmysłów;

4. Systematyczne uprawianie sportu przez niepełnosprawnych jest kontynuacją rehabilitacji oraz czynnikiem utrwalającym efekty lecznicze uzyskane w jej wcześniejszych fazach [...]" (Sobiecka, 2000, s. 77).

Uniwersalizm sportu jako element poprawy jakości życia osób niepełnosprawnych stał się przedmiotem strategii i normatywnych uregulowań wielu organizacji międzynarodowych, państw oraz rządów niemal całego świata. W 1978 r. UNESCO ustanowiło „Międzynarodową Kartę o Wychowaniu Fizycznym i Sporcie”, która była rezultatem współpracy z Międzynarodowym Komitetem Olimpijskim. Między innymi zapisy dokumentu stanowią, że ,[...] dostęp do wychowania fizycznego i sportu powinien zostać zapewniony i zagwarantowany dla wszystkich 
istot ludzkich" (International Charter of Physical Education and Sport, 1978). W 1982 r. na mocy rezolucji Zgromadzenia Ogólnego ONZ przyjęto „Program Działań na rzecz Osób Niepełnosprawnych”. W programie zawarte są zalecania, które zobowiązują wszystkie kraje do wspierania wszelkich form sportowych i rekreacyjnych osób niepełnosprawnych poprzez inwestycje w odpowiednie urządzenia i właściwą organizację tej działalności (World Programme of Action Concerning Disabled Persons, 1982). Następnie w 1993 r. ONZ przyjęła dokument o nazwie „Standardowe Zasady Wyrównywania Szans Osób Niepełnosprawnych", w którym również zostało zaakcentowane prawo do aktywności sportowej i rekreacyjnej osób niepełnosprawnych (The Standard Rules on the Equalization of Opportunities for Persons with Disabilities, 1993). Na 61 sesji Zgromadzenia Ogólnego ONZ w dniu 13 grudnia 2006 r. została przyjęta „Konwencja Praw Osób Niepełnosprawnych". W myśl zapisów tego dokumentu osoby niepełnosprawne posiadają prawo do udziału na zasadzie równości z innymi osobami w działalności rekreacyjnej, wypoczynkowej i sportowej. Między innymi art. 30 pkt 5 zobowiązuje wszystkie kraje do podjęcia odpowiednich środków, aby:

„(a) Promować i zachęcać osoby niepełnosprawne do uczestnictwa, w jak najszerszym zakresie, we wszystkich obszarach działalności sportowej, należącej do głównego nurtu życia społecznego;

(b) Zagwarantować osobom niepełnosprawnym możliwość organizowania, inicjowania i uczestnictwa $\mathrm{w}$ działalności sportowej i rekreacyjnej skierowanej do osób niepełnosprawnych, oraz zachęcać do zapewniania w tym celu środków, szkolenia i nauki, na zasadzie równości;

(c) Zagwarantować osobom niepełnosprawnym dostęp do miejsc, w których prowadzona jest działalność sportowa, rekreacyjna i turystyczna;

(d) Umożliwić dzieciom niepełnosprawnym uczestnictwo w zabawach i zajęciach rekreacyjnych i sportowych, w tym w zajęciach organizowanych w ramach systemu szkolnego, na równych zasadach z innymi dziećmi;

(e) Zapewnić, osobom niepełnosprawnym dostęp do usług w zakresie sportu, rekreacji, turystyki i innych form spędzania wolnego czasu" (Konwencja Praw Osób Niepełnosprawnych, 2006).

Słowa przysięgi składanej przez uczestników olimpiad specjalnych „Pragnę zwyciężyć - lecz jeśli nie będę mógł zwyciężyć, niech będę dzielny w swoim wysiłku" akcentują, że nie jest najważniejsza wygrana nad innymi zawodnikami, ale zwycięstwo z własnymi słabościami i postępowanie zgodnie z regułami „czystej gry”. „Fair play” również w rywalizacji sportowej niepełnosprawnych jest przesłaniem, którego potencjalne korzyści - zarówno indywidualne, jak i społeczne - warunkują rozwój sportu, olimpizmu, jak również są nośnikiem humanistycznych wartości w innych dziedzinach życia (Kaźmierczak, 2010, s. 6). Warto wspomnieć, że zasada „fair play” uczy przede wszystkim: tolerancji dla odmienności rasowej, narodowościowej, religijnej, potrzeby doskonalenia siebie, pokojowego współistnienia między ludźmi, dobrowolnego poszanowania i respektowania 
norm i przepisów określających zasady współżycia społecznego, zaufania do innych ludzi i wiary w ich dobro. Wydaje się, że postawy „fair play” są częściej spotykane w rywalizacji sportowej niepełnosprawnych niż w sporcie wyczynowym, młodzieżowym i rekreacyjnym zawodników pełnosprawnych (Dąbrowska, Dąbrowski, 1995, s. 153). Wskazane zachowanie wynika z większej wrażliwości tej społeczności na potrzeby i oczekiwania innych osób oraz jest skutkiem poczucia grupowej solidarności. W obliczu zachwiania humanistycznych wartości sportu, A. i A. Dąbrowscy propagują ideę upowszechniania zasady „fair play” na gruncie wspólnego uczestnictwa zawodników niepełnosprawnych i pełnosprawnych w różnego rodzaju zawodach sportowych. Ze względu na konieczność kategoryzacji sportowców niepełnosprawnych - równość szans i identyczne warunki współzawodnictwa - istotnym wydaje się postulat przestrzegania zasady „fair play” przez zespoły ludzi zaangażowanych w przygotowanie uczestnictwa niepełnosprawnych do rywalizacji sportowej. W tej dziedzinie osoby niepełnosprawne nadal doświadczają wielu problemów z zabezpieczeniem odpowiednich urządzeń, brakiem wykwalifikowanej kadry trenerów czy dostępem do szkoleń i zasobów wykorzystywanych przez sportowców pełnosprawnych.

Podsumowując powyższe rozważania, należy jednoznacznie stwierdzić, że aktywność sportowa jest doskonałym środkiem wspierania osób niepełnosprawnych w pozyskaniu umiejętności społecznych, skutecznej komunikacji ze środowiskiem zewnętrznym, umiejętności współpracy w zespole, samodyscypliny, szacunku dla innych i przestrzegania określonych zasad. W procesie rehabilitacji należy położyć znaczący akcent na szeroko pojętą aktywność sportową (kwalifikowaną i rekreacyjną), która umożliwi optymalny i wszechstronny rozwój oraz przygotowanie do samodzielnego życia, w którym osoby niepełnosprawne będą pełnić przydatne role, zgodne ze swoimi możliwościami, zainteresowaniami i oczekiwaniami środowiska społecznego.

\section{Bibliografia}

Biniakiewicz B., Olimpizm jako źródło tworzenia nowych wartości w życiu osób niepetnosprawnych, [w:] J. Lipiec (red.), Logos $i$ etos polskiego olimpizmu, Wydawnictwo AWA, Kraków 1994.

Dąbrowska A., Dąbrowski A., Fair play w sporcie niepetnosprawnych, „Wychowanie Fizyczne i Zdrowotne" 1995, nr 4.

Grzegorzewska M., Listy do młodego nauczyciela, Wydawnictwo WSPS, Warszawa 1996.

International Charter of Physical Education and Sport, 21 November 1978, http://portal.unesco.org/ en/ (dostęp: lipiec 2013).

Iwaniszewska M., Udziat i osiagnięcia medalowe polskich sportowców niepetnosprawnych $w$ Letnich Igrzyskach Paraolimpijskich, http://www.paralympic.org.pl/ (dostęp: lipiec 2013). 
Kaźmierczak A., Idea olimpizmu jako alternatywna koncepcja edukacyjno-wychowawcza, [w:] W. Żukow (red.), Humanistyczne aspekty rehabilitacji, turystyki, rekreacji i sportu, Wydawnictwo Ośrodek Rekreacji, Sportu i Edukacji w Poznaniu, Lwów-Poznań-Warszawa 2010.

Konwencja Praw Osób Niepełnosprawnych, 13 December 2006, http://www.unic.un.org.pl/ (dostęp: lipiec 2013).

Maszczak T., Rola aktywności ruchowej w pomnażaniu szans życiowych niepetnosprawnych, „Wychowanie Fizyczne i Sport" 1997, nr 1-2.

Milanowska K., Sport i aktywność ruchowa jako istotny czynnik w rehabilitacji osób niepetnosprawnych, [w:] J. Ślężyński (red.), Sport w rehabilitacji niepetnosprawnych, Wydawnictwo Agat, Kraków 1999.

Sobiecka J., Rola sportu w procesie kompleksowej rehabilitacji polskich uczestników Igrzysk Paraolimpijskich, Wydawnictwo AWF, Studia i Monografie nr 9, Kraków 2000.

Sobiecka J., Sport osób niepetnosprawnych jako czynnik utrwalajacy efekty leczenia i usprawniania, „Wychowanie Fizyczne i Sport” 2001, nr 1.

The Standard Rules on the Equalization of Opportunities for Persons with Disabilities, 20 December 1993, http://www.un.org/disabilities/ (dostęp: lipiec 2013).

World Programme of Action Concerning Disabled Persons, 3 December 1982, http://www.un.org/ disabilities/ (dostęp: lipiec 2013).

Wybraniec-Lewicka B., Wspótczesny sport osób niepelnosprawnych z perspektywy wartości olimpizmu, „Kultura Fizyczna” 2004, nr 1-2.

Żukowska Z., Pedagogiczne uwarunkowania efektywności leczniczej i aktywności sportowej a akceptowany system wartości, [w:] J. Ślężyński (red.), Sport w rehabilitacji niepełnosprawnych, Wydawnictwo Agat, Kraków 1999. 